Received 17 June 2020

Accepted 4 February 2021

Link to DOI:

10.25220/WNJ.V05.11.0015

Journal Website:

www.worldnutrijournal.org

\section{The correlation between body mass index and the risk of osteoporosis in Acehnese adult females in Zainoel Abidin General Hospital}

Nadia Safhira Putri A, ${ }^{1}$ Husnah, ${ }^{2}$ Safrizal Rahman, ${ }^{3}$

\begin{abstract}
Background: Osteoporosis is a condition in which bone become weak and brittle characterized with lower bone density and quality causing increased risk of fracture. The elderly is the most common group to be affected and female is more prone compared to male. One of modifiable risk factors of osteoporosis is low body mass index or underweight. This study aimed to investigate the correlation between body mass index and the risk of osteoporosis on Acehnese adult females in RSUDZA.

Methods: This was an analytic observational-cross sectional study which was completed at the Internal Medicine and Orthopedic Policlinic at Zainoel Abidin General Hospital Banda Aceh from August $27^{\text {th }}$ to September $13^{\text {th }} 2019$. The sampling method used was nonprobability sampling with accidental sampling technique. The body mass index was obtained by measuring respondents' height and weight while the risk of osteoporosis was assessed by measuring OSTA Score.

Results: Results showed that most of respondents was aged between $40-45$ years old (55.4\%) and there are 62 respondents (74.7\%) with abnormal body mass index consisted of 9 underweight respondents (10.8\%), 11 overweight respondents (13.3\%), and 42 obese respondents (50.6\%). The risk of osteoporosis was dominantly mild (69.9\%). There were 7 underweight respondents (77.8) had moderate risk of osteoporosis while 2 underweight respondents had severe risk (22.2\%). Meanwhile, 41 obese respondents had mild risk of osteoporosis (97.6\%). Correlation test using Spearman showed $p$ value $0.000(p<0.05)$ and $r s=-0,731$ which means that there is a strong correlation between body mass index and the risk of osteoporosis.

Conclusions: Lower body mass index is directly proportional with higher risk of osteoporosis.

Keywords body mass index, risk of osteoporosis, OSTA score, Acehnese
\end{abstract}

\section{Introduction}

Osteoporosis is a condition in which bone become weak and brittle characterized with lower bone density and quality causing increased risk of fracture. ${ }^{1}$ Osteoporosis is mainly found on elderly because of decreased bone tissue associated with \

\section{Corresponding author:}

Nadia Safhira P.A

Faculty of Medicine, Syiah Kuala University, Aceh, Indonesia

Email: naya.safhira@gmail.com aging process. In menopause female, the process become quicker due to lower estrogen hormone. ${ }^{2}$

Asians commonly had lower bone mass compared to other population. The bone density on Cambodian, Lao and Vietnamese female in Rochester, United States of America, were lower compared to the white ethinicity. ${ }^{3}$ An Asian statistic according to International Osteoporosis Foundation (IOF) estimated that there will be more than 50\% hip fracture cases due to osteoporosis in Asia in 2050. This is resulted by low calcium intake of all Asian 
countries population which is only $1000-1300$ $\mathrm{mg} /$ day. ${ }^{4}$

International Osteoporosis Foundation (IOF) mentioned that 1 out of 4 Indonesian 50-80 years of age females has the risk of osteoporosis. ${ }^{5}$ This is supported by Perhimpunan Osteoporosis Indonesia (PEROSI) in 2007 which stated that the proportion of population with osteoporosis was $32.3 \%$ on female and $28.8 \%$ on male. ${ }^{5}$ Data from Zainoel Abidin General Hospital also showed that the number of osteoporotic patients visit on Internal Medicine Policlinic in 2018 was 586 patients consisted of 394 females and 192 males.

The risk factors of osteoporosis are age, gender, history of fracture, lifestyle (alcohol consumption and smoking behavior), and low body mass index (underweight). ${ }^{5} \mathrm{~A}$ study by Sri Prihatini et $\mathrm{al}^{6}$ in three provinces which are North Sulawesi, Yogyakarta, and West Java showed that body mass index lower than $18.5 \mathrm{~kg} / \mathrm{m}^{2}$ is the predisposition risk which has significant correlation with the risk of osteoporosis.

Many instruments had been developed to predict low Bone Mineral Density (BMD) including Osteoporosis Self Assessment Tool for Asian (OSTA). This instrument is simple and easy to use for clinician in measuring the risk of osteoporosis in female. (7) This study will explain the correlation between body mass index and osteoporosis in Acehnese adult females at Zainoel Abidin General Hospital.

\section{Methods}

This is an analytic observational study with cross sectional design. The study was conducted at Internal Medicine and Orthopedic Policlinic of Zainoel Abidin General Hospital Banda Aceh from August $27^{\text {th }}$ to September $13^{\text {th }}, 2019$.

\section{Participants}

The population of study are Acehnese adult females treated at Internal Medicine and Orthopedic Policlinic of Zainoel Abidin General Hospital. Samples were part of population fulfilling inclusion and exclusion criteria. The inclusion criteria are: 1 . Patients of Internal Medicine Policlinic of Zainoel Abidin General Hospital, 2. Patients of Orthopedic
Policlinic of Zainoel Abidin General Hospital, 3. Aged 35-45 years old, and 4. Agreed to be respondent. While the exclusion criteria are: 1 . Previously diagnosed with osteoporosis, 2. Active smoker, 3. History of alcohol consumption, and 4. Currently menopause.

\section{Measurements}

Samples were taken using non probability sampling with accidental sampling method. The size of samples were determined using Slovin Formula. As there were 394 patients with osteoporosis at Zainoel Abidin General Hospital in 2018, samples needed with $10 \%$ inaccuracy tolerance were 80 respondents. Weight and height were measured using weight scale and height measurement tools GEA SMIC ZT120. Data collection procedure were as follow:

1. Researcher completed administration procedure at Zainoel Abidin General Hospital, Banda Aceh.

2. Research collected data of female patients aged 35-45 years old at Internal Medicine and Orthopedic Policlinic of Zainoel Abidin General Hospital Banda Aceh.

3. Patients were classified based on inclusion and exclusion criteria to determine the number of samples.

4. Researcher asked for respondents' permission by signing an informed consent page.

5. Researcher interviewed the respondents regarding general information and measured respondents' weight and height. There were 7 enumerators supported the study which were medical students of Syiah Kuala University with similar perception.

6. The weight measurement was done as follow:

a. Respondents wore casual wear without any accessories nor foot cover,

b. Weight scale was put on flat surface,

c. The scale was calibrated until the needle pointed to zero " 0 ",

d. Respondents were instructed to stand on the weight scale in which feet were positioned in the center,

e. Respondents were instructed to stay calm and stare straight to the front, 
f. Wait until the needle showed the fixed weight result,

g. The result of measurement was noted and recorded,

h. Respondents were asked to get back from the weight scale,

7. The height measurement was done as follow:

a. Socks, hats, and any head covers were removed from respondents,

b. Respondents stood under head ruler with straight position, staring to the front, straight knee, and head on Frankfort horizontal plane,

c. Height was measured from ankle to the crest of the skull using measurement stick,

d. The result of measurement was noted and recorded.

Body Mass Index (BMI) was measured using the formula $=$ weight $(\mathrm{kg}) /$ height $\left(\mathrm{m}^{2}\right)$. The result was then classified into underweight $\left(<18.5 \mathrm{~kg} / \mathrm{m}^{2}\right)$, normal $\left(18.5-22.9 \mathrm{~kg} / \mathrm{m}^{2}\right)$, overweight (23.0-14.9 $\mathrm{kg} / \mathrm{m}^{2}$ ), and obesity $\geq 25.0 \mathrm{~kg} / \mathrm{m}^{2}$. Weight and height were measured using weight scale and height measurement tool SMIC ZT-120. The measurement of OSTA Score was done by inputting the data into OSTA formula $=($ Weight - Age $) \times 0.2$. The result is collected in integer numbers. (8) The result is then categorized into mild risk $(\geq 3)$, moderate risk ( -1 to $2)$, and severe risk $(\leq-2)$. (9) Data was analysed with univariate and bivariate analysis using spearman Rank Correlation Test. The study has been approved by Ethic Committee, Faculty of Medicine Syiah Kuala University and Zainoel Abidin General Hospital Banda Aceh: 179/EA/FK-RSUDZA/2019.

\section{Results}

Data was collected from August $27^{\text {th }}$ to September $13^{\text {th }} 2019$ at Internal Medicine and Orthopedic Policlinic of Zainoel Abidin General Hospital with 83 respondents fulfilling the criteria. The characteristics of respondents included were age, occupation, and education history. Distribution data of respondents' characteristics can be seen on Table 1. Data on Table 1 showed that the majority of respondents were aged between 40-45 years old which were 46 respondents $(55.4 \%)$. The occupation was dominated by housewife $(74.7 \%)$ while the majority of respondents had an education history of senior high school (39.8\%).

The body mass index of respondents can be seen on Table 2. It is shown that most of respondents had body mass index of obesity $(50.6 \%)$ while there were 9 respondents with body mass index of underweight (10.8\%).

Based on data from Table 3, most of respondents had mild risk of osteoporosis which were 58 respondents $(59.9 \%)$ while respondents with moderate risks were $23(27.7 \%)$ and 2 respondents with severe risk $(2.4 \%)$.

Data from Table 4 showed that underweight respondents $(22.2 \%)$ had severe risk of osteoporosis while the whole obese respondents had mild risk of osteoporosis $(97.6 \%)$. The result of statistical analysis using Spearmen Correlation Test showed that there is a correlation between Body Mass Index and the risk of osteoporosis with $\mathrm{p}$ value $0,000(\mathrm{p}$ value $<0.05$ ). The correlation between both variables was negative (-) and the correlation strength with $r_{s}$ $=-0.731$ which means that lower body mass index is proportionally significant with higher risk of osteoporosis.

\section{Discussion}

The majority of respondents were aged between 4045 years old which were 46 respondents $(55.4 \%)$. This result is proportional with study by Prihatini et $a l^{5}$ in North Sulawesi, Yogyakarta, and West Java in which older respondents (46-55 years old) were 554 respondents $(22.8 \%)$ compared to younger respondents (25-35 years old) which were 452 respondents $(18.6 \%)$. The bone turnover rate will increase similar with age because of disrupted bone remodeling process.

Respondents were dominated by housewife $(74.7 \%)$ with history of senior high school (39.8\%) education. This result is supported with the study by Setyawati et $a l^{11}$ on 25-35 years old female in Bogor in which housewife was also dominated the study (87.9\%). Occupation is associated with daily physical activity. According to Widyanti in Laras et $a l,{ }^{12}$ the physical activity of housewife is mainly categorized as mild based on International Physical Activity Questionnaire (IPAQ). 
A study by Regina et $a l^{1}$ on reproductive age female in the subdistrict of Babakan Ciparay, Bandung, West Java, Indonesia, showed that most respondents' last education was senior high school $(35.9 \%)$. There is an association between history of education towards knowledge level especially in medical sector. Subject with high education level tends to understand medical information better compared to subjects with lower education level. ${ }^{13}$

Data from Indonesian Basic Health Research/Riset Kesehatan Dasar (RISKESDAS) 2018 showed that the prevalence of obesity on adult in Indonesia was $21.8 \%$ and Aceh Province is one of provinces with higher prevalence of obesity compared to national $(24.4 \%)$. Factors of obesity includes: limited physical activity, higher energy intake compared to outtake, carbohydrate intake, and the use of hormonal contraception. ${ }^{16}$ Based on the interview with the study respondents, it can be understood the majority of housewives had unhealthy lifestyle including food and limited routine physical activities resulting in obesity.

Menopause is one of osteoporosis risk factors because of decreased estrogen level stimulating the bone remodeling. ${ }^{16,17}$ During pre-menopause period, the decreased of estrogen level was not so significant so that the influence towards bone density is also not significant. ${ }^{16}$

The result of this study shows there was a correlation between body mass index with the risk of osteoporosis with $p$ value of 0.000 ( $p$ value $<0.05$ ). This result is supported with the study by Montazerifar $^{16}$ on 80 post menopause females at Zahedan Rheumatology Clinic, Malaysia, which showed that there is correlation between body mass index and lumbal Body Mass Density (BMD) with $p$ value of 0.002 and correlation coefficient of 0.31 inferring weak correlation. In the newest systematic review, the annual global incidence of hip fracture was higher in Hongkong, Japan, South Korea, and Taiwan, compared to United States of America and Europe. The prevalence in Taiwan was categorized as high incidence country $(>300 / 100,000)$ which was on the $9^{\text {th }}$ position compared to other 61 countries, while Hongkong, Japan, and South Korea was listed on moderate incidence countries (200$300 / 100,000) .^{18}$

A study by Widyanti ${ }^{7}$ in 2017 showed that there is a correlation between total body fat with the bone density on reproductive women (15-49 years old) in Bandung with $p$ value 0.006 and correlation coefficient of 0,327 inferring lower correlation and higher total body fat is proportional with higher bone density.

Balanced diet is crucial for the bone development and maintenance as also for the general health. Certain population such as women above 65 years old, women with decreased appetite due to several reasons, or women with food disruption might not consume vitamin and mineral in optimal amount for bone mass. Older women who lost weight has the risk of osteoporosis and hip fracture. ${ }^{20}$

Based on a Food Consumption Survey in Aceh (2014), the average consumption rate of soy and its product was 12.7 grams per person per day in which groups of 13-18 years old dominated the consumption (13.7 grams). Other than that, the average consumption rate of milk was the highest which is 1.5 grams per person per day. However, the lowest consumption rate of milk was on age group of above 55 and 19-55 years old $(0.2$ and $0.3 \mathrm{~mL}$, respectively). ${ }^{17}$ This result indirectly showed the deficiency of calcium intake of Acehnese especially adults so that the risk of osteoporosis is increased.

Lower body mass index (BMI) or underweight is one of osteoporosis risk factors. Nutrition status is associated with protein and calcium reserve for bone metabolism. ${ }^{17}$ BMI $<20 \mathrm{~kg} / \mathrm{m}^{2}$ is associated with decreased bone density and higher fracture risk. Subjects with higher BMI have better bone mineral content (BMC) and bone mineral density (BMD) on the lower extremities. The result of an observation study showed that the phenomenon is not only associated with the mechanical effect but also the consumed intake calories. ${ }^{22}$ More weight will give more burden to the bone so that the bone density will be increased because of the accommodation process. ${ }^{23,24}$ Mechanical burden of the bone will increase the bone remodelling process and decrease the bone turnover process resulting in stronger bone. ${ }^{12}$

Body fat is essential as protective agent towards fracture. Adipocyte cells are important source of estrogen hormone in which higher hormone level will cause increased other hormones such as leptin, preptin, and amylin. These hormones influences the activity of osteoblast and osteoclast both directly and indirectly in the bone remodeling process. ${ }^{25}$ 
Estrogen is one of sex hormones which plays role in the bone metabolism process by regulating osteoblast and osteoclast activity to balance the remodelling and destruction process. This is caused by the presence of osteoblast receptor on the estrogen hormone, they are alpha and beta receptor (ER $\alpha$ dan ER $\beta) .{ }^{12}$

Subcutaneous and visceral fact have contradicted effects on bone structure. Subcutaneous fact is crucial for bone mass because of its protein as the protective agent in bone growth, that is high amount of adiponectin on subcutaneous fat. ${ }^{25}$ Excessive fat mass will not protect bone from osteoporosis. In subjects with obesity, body visceral fact will increase the bone resorption process via upregulation of proinflammatory cytokines such as IL-6 and TNF- $\alpha$. Produced proinflammatory cytokines will stimulate the bone resorption process via RANKL/RANK/OPG pathway regulation. ${ }^{26}$

Central obesity and inflammation also affect the metabolic syndrome in female. A study by Muherdiyatiningsih $^{27}$ in 2008 on female adult aged 30-55 years old in Bogor, West Java, Indonesia showed that female above 44 years old had twice the risk of developing metabolic syndrome. Metabolic syndrome is a predictor of degenerative diseases such as diabetes melitus and coronary heart disease. Obese subjects will also have a difficulty in the daily activities because of limited movements causing balance problem and increased risk of injury. Therefore, it is important to maintain ideal body weight. ${ }^{28}$

The result of this study is different with the study by Martanti $^{29}$ in 2015 to 81 female adults in Tengaran which showed that there is no correlation between body mass index and osteoporosis with $\mathrm{p}$ value 0.708 . The result also contradicted with Humaryanto $^{14}$ in 2019 in 347 female adults in Jambi which stated that there is no correlation between body mass index and bone mineral density. The difference of result is caused by the dominance of normal body mass index causing the tendency of similar result and interval. Other factors such as genetic and ethnicity also influence the bone density, fat mass, and muscle mass. ${ }^{30}$ Factors such as ethnicity, genetic, smoking, excessive alcohol consumption, limited physical activity, low calcium intake and vitamin $\mathrm{D}$, as also endocrine and metabolic disruption will also increase the risk of osteoporosis. Therefore, the identification and modification of risk factors are needed to decrease the incidence of osteoporosis and fracture in the near future.

\section{Conclusion}

The majority of respondents have abnormal body mass index which were 62 respondents $(74.7 \%)$ consisted of 9 underweight respondents (10.8\%), 11 overweight respondents $(13.3 \%)$, and obese respondents $(50.6 \%)$. It is also noted that 58 respondents had mild risk of osteoporosis $(69.9 \%)$, 23 respondents with moderate risk $(27.7 \%)$, and 2 respondents with severe risk $(2.4 \%)$. In conclusion, there was a correlation between body mass index and the risk of osteoporosis in Acehnese adult females at Zainoel Abidin General Hospital with $p$ value of $0.000(p<0.05)$ and $r s=-0.731$ with strong correlation. This implies that lower body mass index is proportional with higher risk of osteoporosis. It is recommended for the next study to use Mini Nutritional Assessment (MNA) as the nutritional measurement method and to explore more information regarding to the subjects' nutrition intake. 
Table 1. General characteristics of respondents $(n=83)$

\begin{tabular}{lcc}
\hline General Characteristics & Frequency (n) & Percentage (\%) \\
\hline Age & & \\
35-39 years old & 37 & 44.6 \\
$\quad$ 40-45 years old & 46 & 55.4 \\
Occupation & & \\
$\quad$ Housewife & 62 & 74.7 \\
Civil servant & 15 & 18.1 \\
Non-civil servant & 6 & 7.2 \\
History of education & & \\
$\quad$ Primary School & 9 & 10.8 \\
Junior High School & 20 & 24.1 \\
Senior High School & 33 & 39.8 \\
College & 21 & 25.3 \\
\hline
\end{tabular}

Table 2. Distribution of body mass index

\begin{tabular}{lcc}
\hline Body mass index & Frequency (n) & Percentage (\%) \\
\hline Underweight & 9 & 10.8 \\
Normal & 21 & 25.3 \\
Overweight & 11 & 13.3 \\
Obese & 42 & 50.6 \\
\hline
\end{tabular}

Table 3. Distribution of osteoporosis risk in subjects

\begin{tabular}{lcc}
\hline Risk of osteoporosis & Frequency $(\mathbf{n})$ & Percentage (\%) \\
\hline Mild & 58 & 69.9 \\
Moderate & 23 & 27.7 \\
Severe & 2 & 2.4 \\
\hline
\end{tabular}

Table 4. The correlation between body mass index and the risk of osteoporosis

\begin{tabular}{|c|c|c|c|c|c|c|c|c|c|c|}
\hline \multirow{3}{*}{$\begin{array}{l}\text { Body mass } \\
\text { index }\end{array}$} & \multicolumn{10}{|c|}{ Risk of Osteoporosis } \\
\hline & \multicolumn{2}{|c|}{ Mild } & \multicolumn{2}{|c|}{ Moderate } & \multicolumn{2}{|c|}{ Severe } & \multicolumn{2}{|c|}{ Total } & \multirow{2}{*}{$\mathbf{r}_{\mathrm{s}}$} & \multirow{2}{*}{ p Value } \\
\hline & $\mathbf{n}$ & $\%$ & $\mathbf{n}$ & $\%$ & $\mathbf{n}$ & $\%$ & $\mathbf{n}$ & $\%$ & & \\
\hline Underweight & 0 & 0 & 7 & 77.8 & 2 & 22.2 & 9 & 100 & \multirow{4}{*}{-0.731} & \multirow{4}{*}{0.000} \\
\hline Normal & 8 & 38.1 & 13 & 61.9 & 0 & 0 & 21 & 100 & & \\
\hline Overweight & 9 & 81.8 & 2 & 18.2 & 0 & 0 & 11 & 100 & & \\
\hline Obesity & 41 & 97.6 & 1 & 2.4 & 0 & 0 & 42 & 100 & & \\
\hline
\end{tabular}




\section{Conflict of Interest}

Authors declared no conflict of interest regarding this article.

\section{Open Access}

This article is distributed under the terms of the Creative Commons Attribution 4.0 International Licence (http://creativecommons.org/licenses/by/4.0/), which permits unrestricted use, distribution, and reproduction in any medium, provided you give appropriate credit to the original author(s) and the source, provide a link to the Creative Commons license, and indicate if changes were made.

\section{References}

1. Szulc P, Bouxsein ML, Compston JE. Vertebral Fracture Initiative: Overview of osteoporosis: Epidemiology and clinical management. Int Osteoporos Found. 2017;

2. Sefrina A, Re!MediaService. Osteoporosis The Silent Disease. Maya, editor. Yogyakarta: Rapha Publishing; 2016.

3. Thambiah SC, Yeap SS, Chretien G, Martin F. Osteoporosis in South-East Asian Countries. Clin Biochem Rev. 2020;41(1):29-40.

4. International Osteoporosis Foundation (IOF). KEY STATISTICS FOR ASIA [Internet]. 2020 [cited 2020 Dec 24]. Available from: https://www.osteoporosis.foundation/factsstatistics/key-statistic-for-asia

5. Kementerian Kesehatan RI. Data \& Kondisi Penyakit Osteoporosis di Indonesia [Internet]. Infodatin Pusat Data dan Informasi Kementrian Kesehatan RI. 2015. p. 1-8. Available from: http://www.depkes.go.id/download.php?file=downloa d/pusdatin/infodatin/infodatin-osteoporosis.pdf

6. Nuti R, Brandi ML, Checchia G, Di Munno O, Dominguez L, Falaschi P, et al. Guidelines for the management of osteoporosis and fragility fractures. Intern Emerg Med [Internet]. 2019;14(1):85-102. Available from: https://doi.org/10.1007/s11739-0181874-2

7. C Cooper, Ferrari S. IOF Compendium of Osteoporosis. First Edit. Mitchell P, Harvey N, Dennison E, editors. Switzerland; 2017. 76 p.

8. Misra A. Ethnic-Specific Criteria for Classification of Body Mass Index: A Perspective for Asian Indians and American Diabetes Association Position Statement. Diabetes Technol Ther [Internet]. 2015;17(9):667-71. Available

from: http://www.liebertpub.com/doi/10.1089/dia.2015.0007
9. Prihatini S, Mahirawati VK, Jahari AB, Sudiman H. Faktor Determinan Risiko Osteoporosis di Tiga Provinsi di Indonesia. Media Litbang Kesehat [Internet]. 2010;XX(2):91-9. Available from: http://bpk.litbang.depkes.go.id/index.php/MPK/article/ viewFile/787/875

10. Montazerifar F, Karajibani M, Alamian S, Sandoughi M, Zakeri Z, Dashipour AR. Age, Weight and Body Mass Index Effect on Bone Mineral Density in Postmenopausal Women. Heal Scope. 2014;3(1).

11. Edwards BJ. Osteoporosis Risk Calculators. J Clin Densitom [Internet]. 2017;20(3):379-88. Available from: http://dx.doi.org/10.1016/j.jocd.2017.06.024

12. Ristati L, Widyanti E, Kusumastuty I, Arfiani EP. Hubungan Komposisi Tubuh dengan Kepadatan Tulang Wanita Usia Subur di Kota Bandung. Indones J Hum Nutr. 2017;4(1):23-33.

13. Cosman F, de Beur SJ, LeBoff MS, Lewiecki EM, Tanner B, Randall S, et al. Clinician's Guide to Prevention and Treatment of Osteoporosis. Osteoporos Int. 2014;25(10):2359-81.

14. Akesson K, Mitchell P. Capture the fracture. Osteoporos Int. 2013;

15. Helmi NZ. Buku Ajar Muskuloskeletal. Suslia A, editor. Jakarta: Penerbit Salemba Medika; 2013.

16. Sherwood L. Fisiologi Manusia Dari Sel ke Sistem. 8th ed. Penerbit Buku Kedokteran EGC; 2014. 716, 766$767 \mathrm{p}$.

17. Ferrari SL. Pocket Reference to Osteoporosis. Pocket Reference to Osteoporosis. 2018. 1-10 p.

18. Cheung EYN, Tan KCB, Cheung C-L, Kung AWC. Osteoporosis in East Asia: Current issues in assessment and management. Osteoporos Sarcopenia [Internet]. 2016;2(3):118-33. Available from: http://dx.doi.org/10.1016/j.afos.2016.07.001

19. Duque G, Kiel DP. Osteoporosis in older persons: Advances in pathophysiology and therapeutic approaches: Second edition. In: Osteoporosis in Older Persons: Advances in Pathophysiology and Therapeutic Approaches: Second Edition. 2016. p. 1-282.

20. Mendoza N. The importance of diet in osteoporosis. 2013;2013(May):79-84.

21. Kartono D, Hermina, Faatih M. BUKU STUDI DIET TOTAL SURVEI KONSUMSI MAKANAN INDIVIDU PROVINSI ACEH 2014. Lembaga Penerbit BADAN PENELITIAN DAN PENGEMBANGAN KESEHATAN; 2014.

22. Tomlinson DJ, Erskine RM, Morse CI, Onambélé GL. Body fat percentage, body mass index, fat mass index and the ageing bone: Their singular and combined roles linked to physical activity and diet. Nutrients. 2019;11(1).

23. International Osteoporosis Foundation. Osteoporosis and you What is osteoporosis? Int Osteoporos Found [Internet]. 2018; Available from: https://www.iofbonehealth.org/sites/default/files/PDFs /osteoporosis_and_you_english.pdf

24. Dawson-Hughes B, Fuleihan GE-H, Clark P. Bone Care for the Postmenopausal Woman. Int Osteoporos Found 
[Internet]. 2013; Available from: http://www.iofbonehealth.org/epidemiology

25. Mazocco L, Chagas P. Association between body mass index and osteoporosis in women from northwestern Rio Grande do Sul. Rev Bras Reumatol (English Ed [Internet]. 2016;57(4):299-305. Available from: http://dx.doi.org/10.1016/j.rbre.2016.10.002

26. Cao JJ. Effects of obesity on bone metabolism. J Orthop Surg Res. 2011;6(1):30.

27. Muherdiyantiningsih, Ernawati F, Rustan E, Herman S. SINDROM Metabolik pada Orang Dewasa Gemuk di Wilayah Bogor. 2008;31(2):75-81.

28. Rahmani SM, Probosari E. Hubungan Indikator Obesitas dengan Kepadatan Tulang pada Wanita Dewasa Awal. J Nutr Coll. 2016;5(Jilid 4):444-51.

29. Eko Martanti L, Hesti KY, Laska Y. Hubungan Faktor Risiko Umur, Indeks Massa Tubuh, Kebiasaan Olahraga dan Konsumsi Kafein Dengan Gejala Osteoporosis pada Akseptor KB DMPA Di Wilayah
Puskesmas Tengaran. J Kebidanan. 2018;8(1):22-8.

30. Syauqy A. Gambaran Indeks Massa Tubuh dan Densitas Massa Tulang sebagai Faktor Risiko Osteoporosis pada Wanita The Profile of Body Mass Index and Bone Mass Density Scan as Osteoporosis Risk Factor among Female. 2019;30(3):218-22.

31. WHO Scientific Group on the Prevention and Management of Osteoporosis. Prevention and management of osteoporosis : report of a WHO scientific group. World Health Organization. 2000. https:/apps.who.int/iris/handle/10665/ 